problem. This might lead to more timely consideration of TB in the differential of all patients admitted to the hospital, regardless of the skin-test result. To maximize the utility of screening, perhaps only patients on nonsurgical services need be tested. Although we tested for anergy, this is not a recommended screening practice currently, because anergic patients and TST-negative patients are treated the same. Placing only TSTs would minimize reagent and equipment costs, as well as the time needed for testing.

Considerations besides supplies will have to be incorporated into any routine screening program. We had a definitive mechanism for placing results in the chart, but anecdotal experience suggests that the results of TSTs placed by nursing or house staff often are not well documented. Also, the task of placing and interpreting TSTs often falls to healthcare workers in training or floor nurses with little training or experience in the placement and reading of TSTs. Any routine program will have to determine who is to place the test and ensure that these persons are trained appropriately.

These results should be verified, with special emphasis perhaps on verifying risk factors and comparing routine TST placement with other strategies for early identification of TB risk, as well as showing the feasibility of performing screening by diverse staff for a sustained period. Given the changing epidemiology of TB, for infection control purposes, strong consideration should be given to reinstituting the routine placement of TSTs upon patient admission to the hospital.

\section{REFERENCES}

1. Centers for Disease Control, Advisory Committee for the Elimination of Tuberculosis. A strategic plan for the elimination of tuberculosis in the United States. MMWR 1989;38(suppl 3):1-25.

2. American Thoracic Society. Control of tuberculosis in the United States. Am Rev Respir Dis 1992;146:1623-1633.

3. Brudney K, Dobkin J. Resurgent tuberculosis in New York City. Human immunodeficiency virus, homelessness, and the decline of tuberculosis control programs. Am Rev Respir Dis 1991;144:745-749.

4. Reichman LB. The U-shaped curve of concern. Am Rev Respir Dis 1991;144:741-742. Editorial.

5. Dooley SW, Villarino ME, Lawrence M, et al. Nosocomial transmission of tuberculosis in a hospital unit for HIV-infected patients. JAMA 1992;267:2632-2634.

6. Williams J, Schneider N, Gilligan ME. Implementing a tuberculosis control program. Am J Infect Control 1995;23:152-155.

7. Jereb JA, Klevens RM, Privett TD, et al. Tuberculosis in health care workers at a hospital with an outbreak of multidrugresistant Mycobacterium tuberculosis. Arch Intern Med 1995; 155:854-859.

8. Wenger PN, Otten J, Breeden A, Orfas D, Beck-Sague CM, Jarvis WR. Control of nosocomial transmission of multidrugresistant Mycobacterium tuberculosis among healthcare workers and HIV-infected patients. Lancet 1995;345:235-240.

9. Centers for Disease Control and Prevention. Guidelines for preventing the transmission of Mycobacterium tuberculosis in health-care facilities, 1994. MMWR 1994;43:1-132.

10. Browder AA, Griffon AL. Tuberculin tine tests on medical wards. Am Rev Respir Dis 1972;105:299-301.

11. Taneja R, Merritt S, Vanek S, Passannante M, Livingston DH. Tuberculin screening of trauma admissions at a university hospital. A preventive strategy. Arch Surg 1995;130:1223-1226; discussion 1226-1227.

12. Janis EM, Allen DW, Glesby MM, et al. Tuberculin skin test reactivity, anergy, and HIV infection in hospitalized patients. Am J Med 1996;100:186-192.

13. Welty C, Burstin S, Muspratt S, Tager IB. Epidemiology of tuberculous infection in a chronic care population. Am Rev Respir Dis 1985;132:133-136.

14. Welke H, Irsigler GB, Kleeberg HH. The diagnostic value of the tine and Mantoux tests in a general hospital. $S$ Afr Med J 1976;50:2073-2076.

15. Simon JA, McVicker SJ, Ferrell CR, Payne CB Jr. Two-step tuberculin testing in a veterans domiciliary population. South Med J 1987;76:866-869.

16. Cobb S, Hall W. Newly identified cluster of diseases. Rheumatoid arthritis, peptic ulcer, and tuberculosis. JAMA 1965;193:1077-1079.

17. Palmer DL, Reed WP. Delayed hypersensitivity skin testing, I: response rates in a hospitalized population. J Infect Dis 1974;130:132-137.

18. Wright PW, Crutcher JE, Holiday DB. Selection of skin test antigens to evaluate PPD anergy. J Fam Pract 1995;41:59-64.

19. Barry MA, Regan AM, Kunches LM, Harris ME, Bunce SA, Craven DE. Two-stage tuberculin testing with control antigens in patients residing in two chronic disease hospitals. $\mathrm{J} \mathrm{Am}$ Geriatr Soc 1987;35:147-153.

20. Palmer DL, Reed WP. Delayed hypersensitivity skin testing, II: clinical correlates and anergy. J Infect Dis 1974;130:138-143.

21. McGowan JE Jr. Hospital tuberculosis: beyond the inner city. Infect Control Hosp Epidemiol 1994;15:510-512.

\title{
Free Access to MEDLINE on WWW
}

\section{Gina Pugliese, RN, MS Martin S. Favero, PhD}

In June 1997, the National Library of Medicine (NLM), a part of the National Institutes of Health, launched a new service to provide all Americans free access to MEDLINE-the world's most extensive collection of published medical infor- mation-over the World Wide Web. Prior to this, users had to register and pay to search MEDLINE and other NLM databases. The address for the National Library of Medicine is http://www.nlm.nih.gov.

There also will be a new, free NLM online service, PubMed, that will allow the public to establish direct web links between MEDLINE abstracts and the publishers of the full-text articles. This new service is the result of a collaboration between the NLM and major science publishers such as the New England Journal of Medicine, Science, Journal of Biological Chemistry, and the Proceedings of the National Academy of Sciences. 